\begin{tabular}{c} 
International Journal of Scientific World, $5(1)(2017) 47-49$ \\
International Journal of Scientific World \\
SPC \\
Website: $\begin{array}{c}\text { ww. sciencepubco.com/index. } h \text { h } / I J S W \\
\text { doi: } 10.14419 / \text { ijsw. } v 5 i 1.7082 \\
\text { Research paper }\end{array}$ \\
\hline
\end{tabular}

\title{
Asbestos base and asbestos free brake lining materials : comparative study
}

\author{
Dinesh Shinde ${ }^{1 *}$, K. N. Mistry ${ }^{2}$ \\ ${ }^{1}$ SVKM's NMIMS MPSTME Shirpur Campus \\ ${ }^{2}$ GIDC Degree Engineering College, Abrama, Navsari \\ *Corresponding author E-mail:dinesh.shinde@nmims.edu
}

\begin{abstract}
Frictional brake lining materials are broadly made of asbestos as their constituent. But asbestos is dangerous for handling due to health hazardous. Asbestos has ample physical, mechanical and tribological properties. The material replacing it should have all these properties with no undermine. In this paper a study on asbestos base and asbestos free brake lining material is presented. Purpose behind this is combine the demerits of asbestos free and asbestos base materials with comparable properties. Some organic waste from farm like banana peel, palm karnel shell, were also tested for the replacement of asbestos and they found worth through comparison with each others.
\end{abstract}

Keywords: Asbestos Free; Asbestos Base; Brake Lining Material; Tribological Properties.

\section{Introduction}

Brake is a supreme part of all the automobiles and machineries without which we cannot imagine them to be completed. They are exploit to reduce the speed and to control the motion of so many things around the globe. Brakes are framed with leverage, some moving parts and important one is lining material to have frictional effect those are utilised to absorb kinetic energy and transform it into other forms. In mechanical brakes, braking has been applied by efficacious utilization of brake lining materials applied on brake shoe. A brake is said to be more effective, if it assimilate more kinetic energy and dissipate it into heat or other form. We could say that more effectual the friction brake lining, the brake could be. Brake linings are formulate with comparatively slushy but stringy and heat-resistant material having a higher tribological properties.

Brake linings are the moulded form of an adhesive material with minute shots, to have frictional effect. Asbestos is used as a base material to furnish a combining effect of all the materials. Asbestos is consisting of six naturally materialised silicate minerals [1] , these all minerals have in familiar their characteristics of asbestos like , they have around 1:20 aspect ratio, thin mascular crystals, with each visible fibre consisting of number of minute structure known as "fibrils" that can be revealed by abrasion and other processes [2]. Asbestos and their composites have been used from several decades with varying compositions, which has good tribological and mechanical properties. Nevertheless, due to health hazards analogous with handling and application of asbestos, there is scope for development of alternative friction lining material. Significant attempts has been staunch to find a substitute material to replace asbestos fibres in their applications. Such attempts have been evolved from various reasons, such as their availability in market and cost effectiveness and more over a short time ago the health related issues. Throughout and after the World War II, some of its participants are not able to get the asbestos fibres for many of things which is needed and drive to find substitute mate- rials for asbestos. Also, the readily availability and less cost of fibre-reinforced cement products, many countries concentrate on above things. The low-cost cellulose fibres as an alternative to asbestos fibres are also evolved. Since several decades, however, well ordered research has been set in several industrialized countries to substitute asbestos fibres in many recent applications, because of distinguished health risks to users [3], [4].

\section{Asbestos base brake lining materials}

Due to its robust physical, chemical and tribological properties asbestos has been used as a friction material because of.

Herbert Frood is first invented asbestos as a brake linings in 1908 [3]. Before using asbestos as a brake linings, various fibre were tested for the heat dissipation properties, as it is the most desirable property a material which is used as brake lining should have, by different scientist including a renowned scientist Dr Gwilym. After their first use as a brake lining material, asbestos are being tested and analysed for heat dissipation, physical and tribological properties.

Some investigators proposed a unprecedented situation of sliding of organic brake pad over a grey iron. When this worn out cast iron disc is again on the pad a dis-analogous structure on the surface with raised surface plateaus. The investigators have studied the formation of physical, mechanical and tribological composition of the surfaces of the brake pads through various techniques like SEM [5].

An analyst under U.S. Department of Energy, Assistant Secretary for Energy Efficiency and Renewable Energy, Office of Transportation Technology presents a report on friction lining material testing. He argue that, in order to achieve the properties required of brakes, most brake materials are consisting of different constituent that's why called as composites of materials. Thousands of different materials are now used in commercial brake components with varying constituents. First Brake liner was a cotton-based material infused with bitumen solution and was used for wagon 
wheels as well as the automobiles of that days. The invention led to the founding of the Ferodo Company, a firm that still supplies brake materials today in the market. Later on brake lining materials were woven, but in the 1920's these were substituted by moulded materials which has crysotile asbestos fibres, and abundant mineral [6].

Researchers establishes a brake test rig which is capable to measure the performance of a drum brake at a typical sliding and environmental situations. The dry and humid environment of brake pad affected the applied forces and vehicle sliding speed. The experimental results displayed that a slight ascent in the friction coefficients between drum and brake lining with growing pressure or speed at dry as well as wet conditions [7].

Effect of all the factors and entering parameters at the time of the braking such as the type of braking, the geometric design of the disc, and the used material have been modelled for the temperature distribution in the disc brake, made to identify all of them. Numerical simulation of ANSYS base is incorporated to investigate the sequential thermal-structural to carry out for the coupled transient thermal field and stress field to evaluate the stress fields and of deformations which are entrenched the disc and the contact pressure on the pads [8].

Manufacturing parameters like moulding pressure, temperature, time, heat treatment time are also being considered by some analyst to optimize the tribological mechanical and physical properties of brake lining material. The parametric design like Taguchi method has been used to evaluate 16 different brake linings materials produced by manufacturing conditions and are also examined for physical properties like surface hardness and porosity, tribological properties friction coefficient and wear, and the relationship between these two properties is also established [9], [10].

\section{Asbestos free brake lining materials}

Table 1: Comparative Properties of Brake Lining Materials

\begin{tabular}{|c|c|c|c|c|c|c|c|}
\hline \multirow[b]{2}{*}{$\begin{array}{l}\text { Sr. } \\
\text { N } \\
\text { o. }\end{array}$} & \multirow[b]{2}{*}{ Properties } & \multicolumn{5}{|c|}{ Brake lining Material } & \multirow[b]{2}{*}{$\begin{array}{l}\mathrm{ZrSi} \\
\mathrm{O} 4 \\
\text { base }\end{array}$} \\
\hline & & $\begin{array}{l}\text { Asbes- } \\
\text { tos } \\
\text { base }\end{array}$ & $\begin{array}{l}\text { Palm } \\
\text { kar- } \\
\text { nel } \\
\text { shell } \\
\text { base }\end{array}$ & $\begin{array}{l}\text { Peri- } \\
\text { winkle } \\
\text { shell } \\
\text { base }\end{array}$ & $\begin{array}{l}\text { Ba- } \\
\text { nana } \\
\text { peels } \\
\text { base }\end{array}$ & $\begin{array}{l}\text { Zir- } \\
\text { cosil } \\
\text { base }\end{array}$ & \\
\hline 1 & $\begin{array}{l}\text { Specific } \\
\text { gravi-ty } \\
(\mathrm{g} / \mathrm{cm} 3)\end{array}$ & 1.6 & $\begin{array}{l}1.12 \\
48\end{array}$ & $\begin{array}{l}1.01- \\
1.89\end{array}$ & 1.26 & 2.54 & 1.96 \\
\hline 2 & $\begin{array}{l}\text { Friction } \\
\text { coeffi- } \\
\text { cient }\end{array}$ & 0.2 & 0.41 & $0.3-0.4$ & 0.4 & 0.46 & 1.96 \\
\hline 3 & $\begin{array}{l}\text { Hardness } \\
\text { val-ues } \\
\text { (HRB) }\end{array}$ & 110 & 92 & $\begin{array}{l}101- \\
116.7\end{array}$ & 98.8 & 95 & 73 \\
\hline 4 & $\begin{array}{l}\text { Compres- } \\
\text { sive } \\
\text { strength } \\
(\mathrm{N} / \mathrm{mm} 2)\end{array}$ & 108 & 103 & 110 & 95.6 & 100 & 105 \\
\hline
\end{tabular}

Asbestos is having the properties suitable as a base material of friction liners, but it is hazardous to health. It is carcinogenic in nature. So there is a scope for its replacement and some researchers have proposed the materials for the replacement of asbestos as base material for brake lining material. A brake lining material must have good mechanical properties such as compressive strength and tensile strength to sustain itself on high loading applications. But these alternative materials can be systematically investigated for their tribological and mechanical properties with the variation of their composition [11].

An investigator had tested $\mathrm{ZrSiO} 4$ for the friction-wear properties. For this aim, density, hardness, friction coefficient and wear behaviour of the samples were tested. Microstructural study of samples before and after sintering and worn surfaces were also perform by using scanning electron microscopy (SEM), and the types of wear and relation between the parameters were determined [12].
Tribological response of $\mathrm{Al} / \mathrm{SiCp}$ is also being investigated over a wide range of sliding conditions of the pin on disc tester. Powder metallurgy technique is being used to invetstigate three regimes of tribological behaviour of the specimens. Few analyst have suggested some phenolic composites for automotive braking applications and studied their tribological properties. An assorted component made up of phenolic resin, $\mathrm{Cu}$ powder, $\mathrm{BaSO} 4, \mathrm{Al} 2 \mathrm{O} 3$ were also tested by some analyst to study different specimen compositions of the components for manufacturing and a pad-on-disc-type wear tester was used. A pin on disc type tester is very familiar type of instrument in tribological and mechanical field for experimentation. Frictional and wear attributes of the specimens very next to the point of contact of the pad with disk made of cast iron were studied. A SEM was used to investigate the properties and also the effect of temperature on behaviour of the pads was investigated at the temperatures about thusands of degrees and pressure of several bar [13].

A derived alternative material for asbestos which is made up palm karnel shell has been proposed by some explorer. A non - asbestos friction material was developed using an agro-waste material base - palm kernel shell (PKS) - along with other ingregients. Taguchi optimization technique was utilised to achieve optimal friction material formulation and optimum manufacturing parameters. A disc brake is investigated with palm karnel shell material [14].

The development of asbestos-free automotive brake pad using periwinkle shell particles as frictional filler is made in some literature. Periwinkle shell is an organic west of farm whose properties have been utilised for the alternative to the hazardous asbestos. Different sets of specimens were prepared and tested for wear and coefficient of friction. Periwinkle shows a similar properties of asbestos, but it loses its properties at high temperature [15].

A semi metallic material formulated from zircosil, barrites, copper fibre, synthetic graphite, nitride butadiene rubber, steel wool and alkyl benzene is also proposed. The purpose of doing the composition is to develop a material with good frictional properties. The ingredients were devided into three groups' that is fibres, fillers and the binder resins [16].

A new asbestos free material is proposed which is made of banana peels with phenol formaldehyde as a binder. Morphological properties, physical, mechanical and wear properties of the brake pad were deliberated [17].

\section{Conclusions}

An asbestos free brake lining material can be developed with the comparable properties like asbestos but they should sustain the properties at high temperature and pressure. However there are some alternative material to asbestos which are able to bring the high temperature and pressure like a material with palm karnel shell as base constituent, a material with Periwinkle shell as major variant, banana peels as a major component, a semi metallic constituent of zircosil as prime importance. All the materials can be have the properties as shown in table 1. Table is form by going through the literature and studying available amount of knowledge on the brake lining materials. The desirable properties a brake lining materials are compared as well. Although, asbestos has excellent physical, mechanical and tribological properties, health hazardous nature of asbestos motivate us to replace it by using other material. From the above table, all the material other than asbestos have more coefficient of friction, which is desirable for a brake lining material. Also other properties of non-asbestos materials are comparable with the asbestos base brake lining material. So, we could say that a composite materials made of non-asbestos materials can replace asbestos in brake lining material.

Base on above comparative study a composite material made up of asbestos free brake lining material, can developed to investigate Tribological and Mechanical properties. Test set-up is shown in Figure 1 is proposed to do that for a drum brake. 


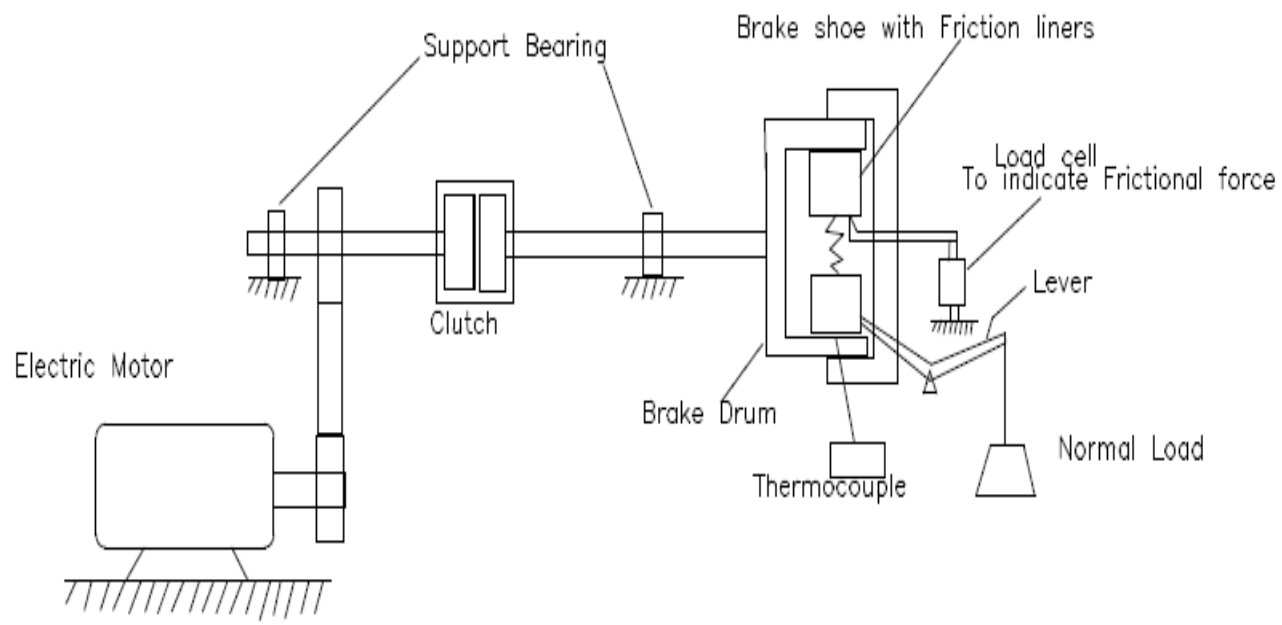

Fig. 1: Test Set Up for Tribological Properties.

\section{References}

[1] Alleman, James E.; Mossman, Brooke T (July 1997). "Asbestos Revisited" (PDF). Scientific American 277: 54-57. https://doi.org/10.1038/scientificamerican0797-70.

[2] Gee, David; Greenberg, Morris (9 January 2002). "As-bestos: from 'magic' to malevolent mineral".

[3] Robert L. Virta, "Asbestos: Geology, Mineralogy, Min-ing, an Uses” Open-File Report 02-149, U.S. Department Of The Interior, U.S. Geological Survey.S

[4] T.P.Newcomb and R.T. Spurr, A Technical History of the Motor Car (Bristol/New York: Adam Hilger, 1989)

[5] Mikael Eriksson, Staffan Jacobson, "Tribological surfaces of organic brake pads" Tribology International 33 (2000) 817-827. https://doi.org/10.1016/S0301-679X(00)00127-4.

[6] Peter J. Blau, 'Compositions, Functions, and Testing of Friction Brake Materials and Their Additives', a report prepared with OAK RIDGE NATIONAL LABORATORY Oak Ridge, Tennessee, 2001.

[7] NOUBY M. GHAZALY, MOSTAFA M. MAKRAHY, "Experimental investigation of drum brake performance for passenger car" Proceedings of The IIER-Science Plus International Conference, Kuala Lumpur Malaysia, 18th October 2014, ISBN: 978-93-8420957-5.

[8] Ali Belhocine, Mostefa Bouchetara, "Investigation of temperature and thermal stress in ventilated disc brake based on 3D thermomechanical coupling model", Ain Shams Engineering Journal (2013) 4, 475-483. https://doi.org/10.1016/j.asej.2012.08.005

[9] Dragan Aleksendric' and Adolfo Senatore, "Optimization of manufacturing process effects on brake friction material wear", Journal of Composite Materials, 46(22) 2777-2791. https://doi.org/10.1177/0021998311432489.

[10] Ferit Ficici, Mesut Durat, Murat Kapsiz, "Optimization of tribological parameters for a brake pad using Taguchi design method" Braz. Soc. Mech. Sci. Eng. (2014) 36:653-659. https://doi.org/10.1007/s40430-013-0115-x.

[11] [I. Mutlu, O. Eldoganb, F. Findikb, "Tribological proper-ties of some phenolic composites suggested for automotive brakes", Tribology International $39 \quad$ (2006) 317-325 https://doi.org/10.1016/j.triboint.2005.02.002

[12] Mustafa BOZ and Adem KURT, "Effect of $\mathrm{ZrSiO} 4$ on the Friction Performance of

[13] Automotive Brake Friction Materials" J. Mater. Sci. Technol., Vol.23 No.6, 2007 843. J.K.M. Kwok, S.C. Lim, "High-speed tribological prop-erties of some $\mathrm{Al} / \mathrm{SiCp}$ composites:I. Frictional and wear-rate characteristics", Composites Science and Technology 59 (1999) 55-63

[14] A. O. A. Ibhadode and I. M. Dagwa, "Development of AsbestosFree Friction Lining Material from Palm Kernel Shell", J. of the Braz. Soc. of Mech. Sci. \& Eng. April-June 2008, Vol. XXX, No. 2 / 167

[15] D.S. Yawas, S.Y. Aku, S.G. Amaren, "Morphology and propertie of periwinkle shell asbestos-free brake pad", Journal of King Saud University - Engineering Sciences (2016) 28, 103-109.
[16] M. A. Sai Balaji, Dr. K. Kalaichelvan, "Optimization of Non Asbestos semi Meatallic Disc Brake pad Formulation with respect to friction and Wear", Procedia Engineering 38(102) 1650-1657.

[17] U.D. Idris, V.S. Aigbodion , I.J. Abubakar , C.I. Nwoye, "Ecofriendly asbestos free brake-pad: Using banana peels" Journal of King Saud University - Engineering Sciences (2015) 27, 185-192.

[18] Mikael Eriksson, Filip Bergman, Staffan Jacobson, "On the nature of tribological contact in automotive brakes, Wear 252 (2002) 2636. https://doi.org/10.1016/S0043-1648(01)00849-3.

[19] M. Kermca,b, M. Kalina,*, J. Vǐzintina, "Development and use of an apparatus for tribological evaluation of ceramic-based brake materials, Wear $259 \quad$ (2005) 1079-187. https://doi.org/10.1016/j.wear.2004.12.002.

[20] Mikael Eriksson, Filip Bergman, Staffan Jacobson, "Surface characterisation of brake pads after running under silent and squealing conditions", Wear $232 \quad 1999 . \quad 163-167$ https://doi.org/10.1016/S0043-1648(99)00141-6.

[21] Ali Belhocine , Mostefa Bouchetara, "Investigation of temperature and thermal stress in ventilated disc brake based on 3D thermomechanical coupling model", Ain Shams Engineering Journal (2013) 4, 475-483. https://doi.org/10.1016/j.asej.2012.08.005.

[22] D. Murali Mohan Rao, Dr. C. L. V. R. S. V. Prasad, T. Ramakrishna, "Experimental and Simulated Studies on Temperature Distribution for Various Disc Brakes", International Journal of Research in Mechanical Engineering \& Technology, Vol. 3, Issue 1, Nov - Apri 12013 